Paedagogia Christiana

I/27 (20I I) - ISSN 1505-6872

Beata Wotosiuk*

Biała Podlaska

\title{
Wartości chrześcijańskie w wychowaniu dzieci w młodszym wieku szkolnym
}

\section{Pojęcie wartości}

Problem wartości był obecny w myśli filozoficznej od czasów starożytnych. Platon (427-347 przed Chr.) uważał, że rzeczy są wartościowe, jeśli uczestniczą w doskonaleniu swych transcendentnych pierwowzorów, które nazywał ideami. Idee są wyznacznikami wartości rzeczy, jeśli same uczestniczą w naczelnej idei dobra. Platon uważał, że dobro jest pierwszą zasadą i ostatecznym celem świata. Znajomość idei - według niego - jest warunkiem właściwego wartościowania rzeczy.

Według św. Tomasza z Akwinu samo istnienie rzeczy, rozumiane jako realny warunek możliwości jakiejkolwiek doskonałości we wszystkich kategoriach bytu, jest podstawową wartością. W związku z tym św. Tomasz sformułował główne aksjomaty swojej aksjologii: Ens et bonum, - et verum, - et unum, - et pulchrum convertuntur ${ }^{1}$. Św. Tomasz uważał, że istotą bytu jest akt, czyli sama doskonałość istnienia tego bytu. Bóg, który jest najwyższym dobrem, jest czystym aktem. Jest pierwszą przyczyną i ostatecznym celem istnienia. Św. Tomasz dzielił dobra na:

- ostateczne, które człowiek wybiera na zasadzie dobrej woli;

- dobra, które wybiera na podstawie sądów intelektualnych.

* Dr Beata Wołosiuk, wykładowca w Państwowej Szkole Wyższej im. Papieża Jana Pawła II w Białej Podlaskiej.

${ }^{1}$ Por. T. Styczeń, Aksjologia, w: F. Gryglewicz, R. Łukaszyk, Z. Sułowski (red.), Encyklopedia katolicka, t. 1, Lublin 1985, kol. 257. 
Jak zauważa S. Kowalczyk, kategoria wartości ma charakter multidyscyplinarny ${ }^{2}$. Wartości są przedmiotem rozważań wielu dyscyplin naukowych. $\mathrm{Z}$ pojęciem tym spotykamy się w sztuce oraz w życiu codziennym. Chociaż intuicyjnie rozumiemy znaczenie tego słowa, często mamy trudności ze zdefiniowaniem go.

W niniejszych rozważaniach szczególnie przydatne wydaje się określenie wartości jako tego, ,co jest godne pożądania”, na zdobyciu czego człowiekowi najbardziej zależy, jako celu, do którego człowiek dąży. Jak pisze M. Nowak:

Wartości wyrażają to, co być powinno i czego pragniemy, wpisują w rzeczywistość pewien sens ostateczny, ukazują to, co naprawdę istotne i do czego warto dążyć. Są filarami, na których opiera się życie społeczne, osobiste i wspólnotowe. Podstawowe zachowania ludzkie są przez nie motywowane i regulowane. Stanowią podstawowy element ludzkich postaw i przyjętego stanowiska ${ }^{3}$.

Wielu filozofów podejmowało próbę uporządkowania wartości. Platon twierdził, że najważniejsza jest następująca triada: prawda, piękno i dobro. Bardziej rozbudowaną hierarchię wartości można spotkać u fenomenologów. M. Scheler wyróżnił pięć grup wartości, tak zwanych modalności, i ustalił ich kolejność:

1. wartości absolutne,

2. wartości duchowe (kulturowe),

3. wartości witalne,

4. wartości utylitarne,

5. wartości hedonistyczne.

Najwyżej - wg Schelera - znajdują się wartości absolutne. Wyróżniał wśród nich święte - przypisywane Bogu, bóstwom, określonym zjawiskom przyrodniczym lub społecznym. Wartościom tym ludzie przypisują najwyższe oceny. Wartościom świętym przeciwstawiane są wartości demoniczne ${ }^{4}$.

Wartości duchowe podzielił na trzy grupy:

- wartości estetyczne,

- wartości poznania prawdy,

- wartości moralne (dobro).

Trzecia grupa to wartości witalne, zwane wartościami życia. Dotyczą one zachowania życia oraz zdrowia psychicznego i fizycznego. Na czwar-

2 S. Kowalczyk, Człowiek w poszukiwaniu wartości. Elementy aksjologii personalistycznej, Lublin 2006, s. 126.

${ }_{3}^{3}$ M. Nowak, Podstawy pedagogiki otwartej, Lublin 2001, s. 393.

${ }^{4}$ P. Brzozowski, Opracowanie skali wartości Schelera, Lublin 1989, s. 41. 
tym miejscu Scheler umieścił wartości tego, co jest użyteczne i nieużyteczne, czyli wartości utylitarne. Uważał on, że nie są one wartościami samoistnymi, ale pochodnymi (na przykład: pilność, roztropność, oszczędność). $\mathrm{Na}$ ostatnim miejscu znajdują się wartości związane z przeżywaniem przyjemności lub przykrości zmysłowych i emocjonalnych, czyli wartości hedonistyczne.

\section{Wartości chrześcijańskie}

Wartości chrześcijańskie to wartości ogólnoludzkie, wzbogacone przez Objawienie. Słusznie pisze M. Nowak, iż „chrześcijanie przyjmują wartości ogólnoludzkie, ale poszukują ich jeszcze większej głębi, ich pełni i integralności, poszukują sensu przekraczającego ten, który zdolny jest nadać im człowiek. Poszukuje się bowiem w chrześcijaństwie jeszcze i tej perspektywy patrzenia na wartości, jaką ma sam Bóg (Objawienie)"`5 . Jak również zauważa M. Nowak, „Wśród chrześcijan pojęcie «zbawienia» zawiera w sobie postęp i wyzwolenie człowieka i w tej kategorii aktywności znajdowałaby się też działalność katechetyczna i ewangelizacyjna, widziane jako wyzwalające i humanizujące. W tym też sensie rozumie się wychowanie w chrześcijaństwie"6. Tak więc, zbawienie chrześcijańskie, które jest darem, jak również zadaniem, domaga się respektowania wartości ogólnoludzkich. „Wartości ogólnoludzkie”, które często bywają określane jako „wartości humanistyczne", wyrosły z wielowiekowego doświadczenia poszczególnych pokoleń, związanego z przeżywaniem tego, co dobre, cenne i święte ${ }^{7}$.

Trudno podać kompletny wykaz tych istotnych wartości. Na pewno będą nimi te wszystkie, które odnoszą się bezpośrednio do osoby ludzkiej w jej podstawowej godności oraz w całości jej praw, tak w wymiarze indywidualnym, jak i społecznym ${ }^{8}$.

Jan Paweł II w przesłaniu papieskim do uczestników Europejskiego Kongresu Naukowego na temat Ku Konstytucji europejskiej, mówił o wartościach chrześcijańskich jako duchowym fundamencie Europy. Ojciec Święty wskazywał na wartości, które dotyczą

${ }^{5}$ M. Nowak, Podstawy, s. 395-396.

${ }^{6}$ Tenże, O wartościach chrześcijańskich w wychowaniu, „Kultura i Edukacja” 2 (1992), s. 45 .

7 Tenże, Podstawy, s. 395.

${ }^{8}$ Zob. G. Confetti, Jan Pawet II $i$ wartości chrześcijańskie w Konstytucji Unii Europejskiej, Kalwaria Zebrzydowska 2007, s. 28-29. 
godności osoby; świętości życia ludzkiego; centralnej roli rodziny opartej na małżeństwie; wagi wykształcenia; wolności myśli, słowa oraz głoszenia własnych poglądów i wyznawania religii; ochrony prawnej jednostek i grup; współpracy wszystkich na rzecz wspólnego dobra; pracy pojmowanej jako dobro osobiste i społeczne; władzy politycznej pojmowanej jako służba, podporządkowanej prawu i rozumowi, a „ograniczonej” przez prawa osoby i narodów ${ }^{9}$.

Historia ludzkości pokazuje, że dla człowieka zawsze ważne były wartości takie jak: prawda, dobro, piękno - określane jako trascendentalia, a więc od niczego niezależne. Chrześcijaństwo sprawiło, że stały się one bardziej otwarte i dynamiczne. ,W różnych ideologiach, w różnych wyznaniach religijnych funkcjonujących na zasadzie ideologii można mówić o specyficznym systemie wartości. Chrześcijaństwo wśród wszystkich innych religii stanowi tutaj wyjątek. Mamy w nim bowiem do czynienia z faktem Wcielenia Boga w naturę ludzką, złączenia wartości boskich i ludzkich"10.

Wartości osobowe, a wśród nich wartości ostateczne (religia, wiara, zbawienie, miłość, nadzieja), powinny być wzbogacone o wartości społeczne (rodzina, ojczyzna, naród, niepodległość, wolność, patriotyzm).

\section{Proces wychowania do wartości chrześcijańskich}

Wartości odgrywają bardzo ważną rolę w edukacji i pedagogice. Wspomagają również rozwój człowieka. Nie jest możliwe wychowanie i kształcenie tożsamości młodego człowieka bez konkretnych „drogowskazów”, czyli wartości. Jak słusznie zauważa K. Popielski,

wartości wiążą ludzką egzystencję z życiem, aktywizują przebieg relacji międzyludzkich i są przedmiotem odniesienia dla jednostki. Przyciagają i otwierają na rzeczywistość, zobowiązują i ukierunkowują. W tym znaczeniu można o nich orzekać w terminach rzeczywistości, które umożliwiają jednostce proces autotransformacji, transformacji, ukierunkowania i podejmowania decyzji ${ }^{11}$.

9 Jan Paweł II, Wartości chrześcijańskie duchowym fundamentem Europy. Przesłanie papieskie do uczestników Europejskiego Kongresu Naukowego nt. «Ku konstytucji europejskiej?», „L'Osservatore Romano” 10-11 (2002).

${ }_{10}$ M. Nowak, Wychowanie a wartości, Zeszyty problemowe kwartalnika „Problemy Edukacji”, Nowy Sącz 1993, s. 53.

${ }_{11}$ K. Popielski, Wartości i ich znaczenie $w$ życiu ludzkim, w: tenże (red.), Człowiekwartości-sens, Lublin 1996, s. 62. 
Jak przekazywać wartości, aby proces ten nie był indoktrynacją zastanawia się M. Nowak, który za O. Reboul podaje przykład Jezusa Chrystusa jako Nauczyciela, który mówiąc o wartościach, nie wykazuje intencji wychowywania, mimo to jednak wychowuje. W związku z tym proponowane są następujące strategie:

1. strategia dysonansu (polega na skonfrontowaniu wychowanka z odmiennymi sposobami myślenia i oceniania);

2. strategia świadectwa (polega na pobudzaniu i wyzwolenia w wychowanku mechanizmu identyfikacji, widzianego jako nieświadome przejęcie pewnych cech drugiej osoby);

3. strategia stymulacji (należy ukonkretnić wartości, na które wychowanek jest już wrażliwy) ${ }^{12}$.

Bardzo ważną formą poznawania wartości jest działanie na rzecz określonych wartości (na przykład w harcerstwie).

Kształcenie aksjologiczne oznacza rozwijanie i doskonalenie w człowieku sfery odpowiedzialnej za sposób rozumienia wartości. K. Olbrycht, rozważając proces wychowania do wartości, twierdzi, że kształcenie aksjologiczne powinno zawierać

pomoc w uzyskaniu wiedzy o wartościach i wartościowaniu oraz w rozwoju struktur i procesów odpowiadających za: umiejętność rozpoznawania sytuacji wyboru, podejmowania decyzji o przyjęciu postawy wartościującej, wybór celów i środków związanych z określonymi wartościami oraz gotowość do podejmowania i umiejętność realizowania odpowiadających tym wartościom działań ${ }^{13}$.

W związku z tym na kształcenie aksjologiczne - według K. Olbrycht składa się:

1. nauczanie o sposobach traktowania wartości, o ich uzasadnianiu, konsekwencjach wyboru wartości;

2. odnoszenie działań wychowawczych do pewnych koncepcji wartości.

Internalizacja wartości będzie możliwa, jeśli wartości zostaną:

- poznane,

- zrozumiane,

- zaakceptowane,

${ }_{12}$ Zob. M. Nowak, Podstawy, s. 423-424.

${ }^{13}$ K. Olbrycht, Prawda, dobro i piękno w wychowaniu człowieka jako osoby, Katowice 2000, s. 88. 
- wytworzy się do nich pozytywny stosunek,

- podjęte zostaną samodzielne wybory i związane z nimi działania na rzecz realizacji tych wartości ${ }^{14}$.

Urzeczywistnianiu wartości sprzyja przestrzeganie następujących zasad:

1. zasada osobowego rozwoju;

2. zasada kształtowania odpowiedzialności za decyzje i wybory;

3. zasada pogłębiania myślenia przyczynowo-skutkowego;

4. zasada własnej autonomii;

5. zasada stałego pogłębiania wiedzy ${ }^{15}$.

Mówiąc o znaczeniu wartości w edukacji i o sposobie przekazywania ich wychowankom, nie można pominąć zagadnienia introcepcji wartości. Introcepcja (łac. intro - do wewnątrz, capere - chwytać, ujmować) to termin, który został wprowadzony przez W. Sterna do personalistycznej psychologii na oznaczenie uznania cudzych wartości i celów za własne.

Problemem tym zajmował się S. Kunowski, który introcepcję wartości rozumiał jako ,proces duchowy rozwijającej się osobowości, polegający na nadaniu lub ustaleniu cechy «wartości» i złączenie jej z pewna rzeczą, celem lub normą"16. Od prawidłowości przebiegu tego procesu autor uzależniał powodzenie całokształtu pracy wychowawczej, w trakcie której wychowanek powinien posiąść umiejętność przypisywania wartości określonym rzeczom, zasadom, normom i celom.

Proces wychowania do wartości wraz z ich introcepcją nie może przebiegać spontanicznie. Autor utożsamia go z zaprezentowaną przez siebie warstwicową teorią wychowania, $\mathrm{z}$ dojrzewaniem osobowości w poszczególnych warstwach przechodzących przez kolejne podłoża. Odpowiadają temu pewne dziedziny wartości:

1. podłoże biologiczne - wartości zmysłowe,

2. podłoże psychologiczne - wartości witalne,

3. podłoże socjologiczne - wartości społeczne,

4. podłoże kulturalne - wartości duchowe,

5. podłoże duchowe - wartości religijne.

W ostatnim stadium - pisze S. Kunowski - „nastapi jakby zlanie się wartości, zupełna odpowiedniość wartości obiektywnej najwyższej (Boga) i wartości subiektywnej, w której następuje «Życie w Bogu» ${ }^{17}$. s. 27.

${ }^{14}$ Por. tenże, Dlaczego boimy się wartości w wychowaniu, „Edukacja i Dialog” 6 (2000),

${ }^{15}$ Zob. K. Ostrowska, Wychowywać do urzeczywistniania wartości, w: K. Olbrycht (red.), Edukacja aksjologiczna, Katowice 1999, s. 23.

${ }^{16}$ S. Kunowski, Wartości w procesie wychowania, Kraków 2003, s. 17.

17 Tamże, s. 51. 
Proces wychowania będzie przebiegał prawidłowo, jeśli nastąpi introcepcja antycypacyjna, czyli na rozwijającym się podłożu nastąpi introcepcja wartości już następnego podłoża. Jeżeli odpowiednia wartość nie pojawi się, wówczas następuje inwolucja - przerwanie dalszego rozwoju, bo - jak pisze autor: „dane podłoże pogłębi się w sobie”"18.

\section{Rola środowiska rodzinnego w wychowaniu do wartości dzieci w mlodszym wieku szkolnym}

Wychowanie, które możemy rozumieć między innymi jako pomoc w przygotowaniu do pełnienia i przyjęcia ról społecznych, formowaniu sumienia, pomoc $\mathrm{w}$ personalizacji ${ }^{19}$, jest niemożliwe bez wartości. W procesie wychowania i kształcenia rodzice odwołują się do wartości, które dziecko poznaje, wybiera, akceptuje, przyjmuje jako swoje i urzeczywistnia.

Za S. Kunowskim możemy określić, że w potocznym rozumieniu wychowanie to „wszelkie celowe oddziaływanie ludzi dojrzałych (wychowawców) przede wszystkim na dzieci i młodzież (wychowanków), aby w nich kształtować określone pojęcia, uczucia, postawy, dążenia"20.

Wychowanie może również oznaczać „,czynną pomoc udzielaną dziecku w jego rozwoju, w aktualizowaniu się jego potencjalnych możliwości [...], jest inspirowaniem do samowychowania, którego warunkiem podstawowym jest rozwój sfery własnej duchowości, a tym samym - własnej samoświadomości aksjologicznej”21 .

Personalizm, który podkreśla niepowtarzalność, godność osoby i jej prawo do wyboru własnej drogi doskonalenia osobowego, jest przeciwny manipulowaniu treściami kształcenia i wychowania. Nie oznacza to jednak, że wychowanie nie powinno być ukierunkowane. Wprost przeciwnie, powinno być zorientowane na pożądane wartości, takie jak prawda, dobro, piękno, wartości humanistyczne, wartości chrześcijańskie.

Najważniejszym, właściwym i pierwszym miejscem, gdzie dokonują się relacje między wychowankiem a wychowawcą jest rodzina. Wpływ środowiska rodzinnego na kształtowanie się wartości dziecka przebiega dwoma torami: jako świadoma praca wychowawcza oraz jako oddziaływanie niezamierzone. Będzie to oddziaływanie poprzez tok czynności i zdarzeń za-

18 Tamże, s. 61.

${ }_{19}$ M. Nowak, Znaczenie wartości w procesie wychowania, w: K. Popielski (red.), Człowiek, s. 254.

${ }^{20}$ S. Kunowski, Podstawy współczesnej pedagogiki, Łódź 1981, s. 15.

${ }^{21}$ W. Dróżka, Wartości edukacyjne osoby nauczyciela, w: T. Kukołowicz, M. Nowak (red.), Pedagogika ogólna. Problemy aksjologiczne, Lublin 1997, s. 353. 
chodzących w rodzinie, poprzez sposób ustosunkowania się do tych zdarzeń i czynności oraz postępowanie rodziców czy też ewentualnie rodzeństwa, a szczególnie przez sposób wzajemnego odnoszenia się członków rodziny do siebie $^{22}$.

M. Ziemska uważa, że właściwymi postawami rodzicielskimi są: akceptacja dziecka, współdziałanie z dzieckiem, dawanie dziecku właściwej dla jego wieku rozumnej swobody, uznanie praw dziecka w rodzinie jako równych, bez przeceniania i niedoceniania jego roli ${ }^{23}$.

Na znaczenie akceptacji dziecka w rodzinie zwraca uwagę T. Kukołowicz. Uważa ona, że akceptacja jest drogą do chrześcijaństwa, ponieważ jest wstępem do miłości.

Akceptacja dziecka to przyjęcie go takim, jakie ono jest, z jego cechami fizycznymi, usposobieniem, z jego możliwościami umysłowymi i łatwością osiagnięć w jednych dziedzinach, a ograniczeniami i trudnościami w innych. [...] Istotę akceptacji stanowi przyjęcie w dziecku człowieka, którego nie wolno nam odrzucać ani potępiać, natomiast możemy ganić jego czyny. [...] Do istoty akceptacji należy również poprawianie wszystkich odchyleń w zachowaniu, naprowadzanie na prostą droge, zgodnie z celem i dobrem dziecka ${ }^{24}$.

Rodzice, którzy są autorytetami dla swoich dzieci, na pewno wpływają w znacznej mierze na wybór ich wartości. Każdy, szczególnie młody człowiek potrzebuje drogowskazu, ukierunkowania, jak ma postępować w życiu, co uznać za priorytet. Rodzic jako autorytet w wychowaniu do wartości powinien wskazywać właściwą drogę w życiu.

Z. Matulka uważa, że proces przekazywania wartości powinien odbywać się poprzez dialog pedagogiczny, który zakłada partnerstwo wychowawcy i wychowanka. Nie tylko wychowawca przekazuje wartości wychowankowi, ale obserwujemy tu interakcję zachodzącą między dwoma podmiotami. Ważne jest, aby zachowania obydwu partnerów były autentyczne ${ }^{25}$.

Świadomość wychowawcza rodziców zależna jest od ich osobistych doświadczeń, warunków społecznych, kulturowych i politycznych. Często lansowany przez środki masowego przekazu konsumpcyjny styl życia, egoizm, przedkładanie kariery zawodowej nad dobro dziecka ma negatywny wpływ

${ }^{22}$ Por. M. Ziemska, Postawy rodzicielskie i ich wplyw na osobowość dziecka. w: tenże (red.), Rodzina i dziecko, Warszawa 1986, s. 155-195.

${ }^{23}$ Tamże.

${ }^{24}$ T. Kukołowicz, Rodzina wychowuje, Stalowa Wola 1998, s. 13.

${ }_{25}$ Zob. Z. Matulka, Przekazywanie wartości w procesie edukacji szkolnej, „Kultura i Edukacja" 1/23 (1998), s. 12-14. 
na kształtowanie świadomości wychowawczej rodziców, a w konsekwencji na wychowanków ${ }^{26}$.

Wiek wczesnoszkolny jest okresem, w którym kształtuje się osobowość dziecka. Jest to szczególny czas podatności na oddziaływania wychowawcze oraz wzmożonej ciekawości poznawczej. Aktywność poznawcza dziecka jest w tym okresie selektywna, systematyczna i strategiczna ${ }^{27}$.

Gdy dziecko osiaga dojrzałość szkolną i rozpoczyna naukę szkolną - jak zauważa M. Przetacznikowa

poszerza się i wzbogaca jego środowisko wychowawcze oraz zmieniają się jakościowo formy oddziaływań pedagogicznych, jakim podlega. Większość dzieci pozostaje nadal, przynajmniej przez okres uczęszczania do szkoły podstawowej, w kręgu wpływów wychowawczych domu rodzinnego, inna staje się jednak ich pozycja w rodzinie, zmieniają się obowiązki, wymagania i przywileje; na nowych zasadach układają się stosunki dziecka z rodzicami, rodzeństwem i krewnymi ${ }^{28}$.

\section{Analiza badań empirycznych dotyczących wychowania do wartości chrześcijańskich dzieci w młodszym wieku szkolnym}

W obecnej części zostaną zaprezentowane wyniki badań dotyczących wychowania do wartości chrześcijańskich dzieci w młodszym wieku szkolnym. Przedstawione będą opinie dzieci klas III szkoły podstawowej oraz ich rodziców mieszkających w powiecie bialskim. Badania zostały przeprowadzone wśród 310 uczniów i ich rodziców.

\subsection{Autorytet dziecka (w opinii rodziców)}

W wychowaniu do wartości uznawanie autorytetów ma bardzo istotną rolę. Szczególnie młody człowiek potrzebuje ukierunkowania, jak ma w życiu postępować. Rodzice wprowadzający dziecko w świat wartości powinni wiedzieć, kto dla ich dziecka jest ważny, kogo uznaje za swój autorytet.

${ }^{26}$ Zob. D. Opozda, Świadomość wychowawcza rodziców, w: R. Piwowarski (red.), Dziecko-Nauczyciel-Rodzice. Konteksty edukacyjne, Białystok-Warszawa 2003, s. 155-161.

27 Zob. M. Kielar-Turska, Rozwój dziecka, w: T. Pilch (red.), Encyklopedia Pedagogiczna XXI wieku, t. V, Warszawa 2006, s. 492.

${ }_{28}$ M. Przetacznikowa, Wychowanie dzieci i młodzieży w wieku szkolnym, w: M. Przetacznikowa, Z. Włodarski (red.), Psychologia wychowawcza, Warszawa 1986, s. 550-551. 
Tabela 1. Autorytet dziecka (w opinii rodziców)

\begin{tabular}{|l|c|c|}
\hline \multicolumn{1}{|c|}{ Autorytet dziecka } & N & \% \\
\hline Rodzice & 194 & 62,6 \\
\hline Rodzina (rodzeństwo, dziadkowie) & 27 & 8,7 \\
\hline Nauczyciel & 101 & 32,6 \\
\hline Ksiądz, katecheta & 20 & 6,5 \\
\hline Papież Jan Paweł II & 15 & 4,8 \\
\hline Znany sportowiec, aktor, muzyk & 11 & 3,5 \\
\hline Nie ma autorytetu & 13 & 4,2 \\
\hline
\end{tabular}

Zdaniem respondentów autorytetem ich dziecka są przeważnie rodzice (tak sądzą 194 osoby, co stanowi 62,6\% wszystkich badanych) i nauczyciele (101 osób - 32,\%). Zdarza się, że autorytetem uczniów bywa ktoś z rodziny, ksiądz, katecheta, Papież Jan Paweł II. 11 rodziców (3,5\%) sądzi, że może być to znana osoba publiczna, na przykład sportowiec, aktor, piosenkarz.

\subsection{Ksztaltowanie wartości w opinii dzieci}

W niniejszej części zostaną ukazane wypowiedzi badanych dzieci na temat czynników, które ich zdaniem wpływają na wartości przez nich preferowane. Poproszono, aby uczniowie wypowiedzieli się, skąd czerpią wiedzę na temat tego, co jest dla nich dobre a co złe, skąd wiedzą, jak należy postępować w życiu. Zdecydowana większość badanych uczniów (253 osoby - co stanowi 81,6\% respondentów) twierdzi, że rodzice wprowadzają ich w świat wartości, 94 osoby wskazuje na nauczycieli (30,3\%), 41 (13,2\%) na księdza lub katechetę, 29 uczniów (9,4\%) uważa, że sami wiedzą, jak należy postępować, jakich wyborów dokonywać. 5,5\% badanych dzieci jest zdania, że rówieśnicy lub środki masowego przekazu wpływają na wybór ich wartości. 13 osób (4,2\%) nie miało zdania na ten temat. 
Tabela 2. Osoby wpływające na wybór wartości a płeć dziecka

\begin{tabular}{|l|c|c|c|c|c|c|}
\hline \multirow{2}{*}{ Wyszczególnienie } & \multicolumn{4}{|c|}{ Pleć dzieci } & \multicolumn{2}{c|}{ Razem } \\
\cline { 2 - 7 } & \multicolumn{2}{|c}{ chłopcy } & \multicolumn{2}{c|}{ dziewczynki } & \multicolumn{2}{c|}{} \\
\cline { 2 - 7 } & $\mathrm{N}$ & $\%$ & $\mathrm{~N}$ & $\%$ & $\mathrm{~N}$ & $\%$ \\
\hline Nie wiem & 10 & 6,5 & 3 & 1,9 & 13 & 4,2 \\
\hline Rodzice & 120 & 77,4 & 133 & 85,8 & 253 & 81,6 \\
\hline Nauczyciele & 39 & 25,2 & 55 & 35,5 & 94 & 30,3 \\
\hline $\begin{array}{l}\text { Sam wiem } \\
\text { (Sumienie) }\end{array}$ & 15 & 9,7 & 14 & 9,0 & 29 & 9,4 \\
\hline Ksiądz, Katecheta & 13 & 8,4 & 28 & 18,1 & 41 & 13,2 \\
\hline Inna odpowiedź & 11 & 7,1 & 6 & 3,9 & 17 & 5,5 \\
\hline Razem & $\mathbf{1 5 5}$ & $\mathbf{1 0 0 , 0}$ & $\mathbf{1 5 5}$ & $\mathbf{1 0 0 , 0}$ & $\mathbf{3 1 0}$ & $\mathbf{1 0 0 , 0}$ \\
\hline
\end{tabular}

Płeć badanych w pewnym stopniu wpływa na sposób udzielanych na powyższy temat odpowiedzi, jednak różnice nie są istotne statystycznie (Chi-kwadrat Pearsona wynosi 3,633; p=0,057).

Tabela 3. Osoby wpływające na wybór wartości a miejsce zamieszkania

\begin{tabular}{|l|c|c|c|c|c|c|}
\hline \multirow{2}{*}{ Wyszczególnienie } & \multicolumn{4}{|c|}{ Typ miejscowości } & \multicolumn{2}{c|}{ Chi-kwadrat Pearsona } \\
\cline { 2 - 6 } & \multicolumn{2}{|c|}{ miasto } & \multicolumn{2}{c|}{ wieś } & \multirow{2}{*}{$\begin{array}{c}\text { Istotność } \\
\text { asymptotycźćna } \\
\text { andwustronna) }\end{array}$} \\
\cline { 2 - 7 } & $\mathrm{N}$ & $\%$ & $\mathrm{~N}$ & $\%$ & & \\
\hline Nie wiem & 5 & 3,1 & 8 & 5,3 & & 0,000 \\
\hline Rodzice & 143 & 89,4 & 110 & 73,3 & 13,276 & 0,01 \\
\hline Nauczyciele & 60 & 37,5 & 34 & 22,7 & 9,223 & 0,000 \\
\hline Sumienie & 6 & 3,8 & 23 & 15,3 & 12,250 & 0,468 \\
\hline Ksiądz, katecheta & 19 & 11,9 & 22 & 14,7 & 0,526 & 0,107 \\
\hline Inna odpowiedź & 12 & 7,5 & 5 & 3,3 & 2,593 & \\
\hline \multicolumn{1}{|c|}{ Razem } & $\mathbf{1 6 0}$ & $\mathbf{1 0 0 , 0}$ & $\mathbf{1 5 0}$ & $\mathbf{1 0 0 , 0}$ & & \\
\hline
\end{tabular}


Przez zastosowanie testu Chi-kwadrat Pearsona można stwierdzić, że odpowiedzi mieszkańców miast i wsi różnią się istotnie statystycznie $\mathrm{w}(\mathrm{p}<0,001)$ jeśli chodzi o odpowiedź „rodzice” i ,sumienie”.

W edukacji aksjologicznej uznawanie autorytetów odgrywa ważną rolę. Młody człowiek powinien posiadać wzorce, którymi miałby się kierować w życiu. Istotne więc wydaje się, kogo chcą naśladować badani uczniowie, kto jest dla nich najważniejszy, czyli kogo uważają za swój autorytet.

Dla większości badanych dzieci rodzina odgrywa najważniejszą rolę w życiu (70\% badanych uważa, że to rodzina, rodzeństwo są najważniejsi w ich życiu, 56,1\% respondentów wymienia rodziców, 17,7\% twierdzi, że Bóg jest dla nich najważniejszy, 11\% wskazuje na kolegów i koleżanki. 14 osób $(4,5 \%)$ podaje, iż ich ulubione zwierzątko jest dla nich najważniejsze w życiü ${ }^{29}$.

Tabela 4. Kto jest najważniejszy w życiu dziecka (rozkład liczebności w zależności od przynależności od płci badanego)

\begin{tabular}{|l|c|c|c|c|c|c|}
\hline \multirow{2}{*}{ Wyszczególnienie } & \multicolumn{4}{|c|}{ Pleć dzieci } & \multicolumn{2}{c|}{ Razem } \\
\cline { 2 - 6 } & \multicolumn{2}{|c|}{ Chłopcy } & \multicolumn{2}{c|}{ Dziewczęta } & \multirow{2}{*}{ N } & \multirow{2}{*}{$\%$} \\
\cline { 2 - 6 } & $\mathrm{N}$ & $\%$ & $\mathrm{~N}$ & $\%$ & & \\
\hline Nie wiem & 1 & 0,6 & 1 & 0,6 & 2 & 0,6 \\
\hline Rodzice & 75 & 48,4 & 99 & 63,9 & 174 & 56,1 \\
\hline Rodzina, rodzeństwo & 103 & 66,5 & 114 & 73,5 & 217 & 70,0 \\
\hline Rówieśnicy & 20 & 12,9 & 14 & 9,0 & 34 & 11,0 \\
\hline Bóg & 25 & 16,1 & 30 & 19,4 & 55 & 17,7 \\
\hline $\begin{array}{l}\text { Ulubione } \\
\text { zwierze }\end{array}$ & 5 & 3,2 & 9 & 5,8 & 14 & 4,5 \\
\hline
\end{tabular}

Odpowiedzi dziewcząt i chłopców różnią się w pewnym stopniu, jednak różnice nie są istotne statystycznie. Dziewczęta częściej niż chłopcy wymieniają rodziców jako osoby najważniejsze w ich życiu. Natomiast rówieśnicy odgrywają większą rolę w życiu badanych chłopców niż w życiu dziewcząt.

29 Część respondentów podawała więcej niż jedną odpowiedź. 
Tabela 5. Kogo chcą naśladować badani uczniowie

\begin{tabular}{|l|c|c|}
\hline \multicolumn{1}{|c|}{ Osoby godne naśladowania } & N & \% \\
\hline Nie wiem & 4 & 1,3 \\
\hline Rodzice & 150 & 48,4 \\
\hline Rówieśnicy & 10 & 3,2 \\
\hline Nauczyciele & 10 & 3,2 \\
\hline Ktoś z rodziny (np. dziadkowie, ciotka) & 6 & 1,9 \\
\hline Papież Jan Paweł II & 6 & 1,9 \\
\hline Osoby popularne np. (znani artyści, sportowcy) & 69 & 22,3 \\
\hline Ksiądz, katecheta & 12 & 3,9 \\
\hline Podany konkretny zawód & 3 & 1,0 \\
\hline Jezus & 23 & 7,4 \\
\hline Rodzeństwo & 12 & 3,9 \\
\hline Nikt & 5 & 1,6 \\
\hline Razem & $\mathbf{3 1 0}$ & $\mathbf{1 0 0 , 0}$ \\
\hline
\end{tabular}

Zdaniem badanych uczniów osoby godne naśladowania to przede wszystkim rodzice - tak uważa prawie połowa badanych $(48,4 \%)$. Dla znacznej grupy badanych $(22,3 \%)$ wzorem do naśladowania są osoby popularne, znane ze środków masowego przekazu (sportowcy, aktorzy, piosenkarze). $7,4 \%$ badanych uczniów twierdzi, że ich wzorem jest Jezus Chrystus.

\subsection{Wartości preferowane przez rodziców}

Hierarchia wartości rodziców będzie miała zapewne wpływ na wartości preferowane przez ich dzieci. Dlatego konieczne wydaje się poznanie hierarchii wartości rodziców.

Tabela 6. Wartości preferowane przez rodziców

\begin{tabular}{|c|l|c|c|}
\hline Lp. & Wartości preferowane przez rodziców & N & \% \\
\hline 1 & rodzina & 200 & 64,5 \\
\hline 2 & ojczyzna, patriotyzm & 181 & 58 \\
\hline
\end{tabular}


Cd. tabeli 6 .

\begin{tabular}{|c|c|c|c|}
\hline Lp. & Wartości preferowane przez rodziców & $\mathbf{N}$ & $\%$ \\
\hline 3 & Bóg, religia & 178 & 57 \\
\hline 4 & uczciwość & 178 & 57 \\
\hline 5 & prawdomówność, prawda & 160 & 51,6 \\
\hline 6 & pokój & 159 & 51,3 \\
\hline 7 & miłość & 158 & 50,9 \\
\hline 8 & wiedza, mądrość, inteligencja & 149 & 48 \\
\hline 9 & dobro & 148 & 47,7 \\
\hline 10 & zdrowie & 148 & 47,7 \\
\hline 11 & szacunek & 130 & 41,9 \\
\hline 12 & honor & 106 & 34 \\
\hline 13 & pomaganie innym & 90 & 29 \\
\hline 14 & sprawiedliwość & 50 & 16 \\
\hline 15 & szczerość & 48 & 15,4 \\
\hline 16 & życzliwość & 46 & 14,8 \\
\hline 17 & konsekwencja & 30 & 9,6 \\
\hline 18 & rzetelność & 20 & 6,4 \\
\hline 19 & radość życia & 15 & 4,8 \\
\hline 20 & pracowitość & 14 & 4,5 \\
\hline 21 & lojalność & 13 & 4,1 \\
\hline 22 & przyjaźń & 13 & 4,1 \\
\hline 23 & odwaga & 10 & 3,2 \\
\hline 24 & tolerancja & 9 & 2,9 \\
\hline 25 & zaufanie & 9 & 2,9 \\
\hline 26 & wierność & 7 & 2,2 \\
\hline 27 & piękno & 6 & 1,9 \\
\hline 28 & kultura osobista & 5 & 1,6 \\
\hline 29 & wolność & 3 & 0,9 \\
\hline 30 & harmonia & 2 & 0,6 \\
\hline
\end{tabular}


Wartościami, które badani rodzice uważają za najważniejsze w ich życiu są: rodzina $(64,5 \%$ badanych wymienia tę wartość), patriotyzm $(58 \%)$, Bóg (57\%), uczciwość $(57 \%)$, prawda $(51,6 \%)$, pokój $(51,3 \%)$, miłość $(50,9 \%)$, wartości poznawcze $(48 \%)$, dobro $(47,7 \%)$ i zdrowie $(47,7 \%)$.

W pierwszym etapie badania (badanie Kwestionariuszem dla rodziców) respondenci zostali poproszeni o podanie własnej hierarchii wartości. Dość duża grupa rodziców $(33,5 \%)$ nie podjęła się tego zadania. Dlatego, aby poznać opinię rodziców na tak istotne zagadnienie dotyczące wartości preferowanych przez rodziców, respondenci zostali poproszeni o wypełnienie Skali Wartości Schelerowskich. Badanie SWS pozwoliło poznać, jakie wartości preferują rodzice. Prezentują się one następująco:

1. Świętości religijne,

2. Świętości świeckie,

3. wartości moralne,

4. wartości prawdy,

5. sprawność i siła fizyczna,

6. wytrzymałość,

7. wartości hedonistyczne,

8. wartości estetyczne.

Najbardziej przez rodziców cenione są wartości religijne, natomiast najmniej wartości estetyczne.

\subsection{Hierarchia wartości badanych dzieci (na podstawie Kwestionariusza dla dzieci)}

Zadaniem badanych uczniów było uporządkowanie według ważności (co według dzieci jest najważniejsze) następujących wartości: wiedza, dobro, piękno, prawda, zdrowie, Bóg, rodzina.

Uczeń nadał każdej wartości określona rangę. Zsumowanie otrzymanych wyników (za każde miejsce dana wartość otrzymała określoną liczbę punktów; pierwsze miejsce 7, drugie 6 itd.) pozwoliło stworzyć hierarchię wartości uczniów edukacji zintegrowanej.

Tabela 7. Hierarchia wartości dzieci

\begin{tabular}{|c|c|c|}
\hline Lp. & Wartość & Liczba punktów \\
\hline 1 & Bóg & 1647 \\
\hline 2 & rodzina & 1541 \\
\hline 3 & zdrowie & 1523 \\
\hline
\end{tabular}


Cd. tabeli 7.

\begin{tabular}{|c|c|c|}
\hline Lp. & Wartość & Liczba punktów \\
\hline 4 & prawda & 1486 \\
\hline 5 & piękno & 1228 \\
\hline 6 & wiedza & 633 \\
\hline 7 & dobro & 622 \\
\hline
\end{tabular}

Tabela 8. Hierarchia wartości dzieci (na podstawie techniki Napisz i narysuj)

\begin{tabular}{|c|c|c|}
\hline Lp. & wartość & liczba punktów \\
\hline 1 & rodzina & 1623 \\
\hline 2 & wartości religijne & 674 \\
\hline 3 & miłość & 406 \\
\hline 4 & dom & 313 \\
\hline 5 & nauka & 276 \\
\hline 6 & przyjaźń & 220 \\
\hline 7 & zdrowie & 208 \\
\hline 8 & hobby & 183 \\
\hline 9 & sport & 142 \\
\hline 10 & przyroda & 132 \\
\hline 11 & ulubione zwierzę & 92 \\
\hline 12 & pożywienie & 84 \\
\hline 13 & dobro & 42 \\
\hline 14 & szczęście & 41 \\
\hline 15 & prawda & 27 \\
\hline 16 & pieniądze & 21 \\
\hline 17 & praca & 20 \\
\hline 18 & pokój, bezpieczeństwo & 19 \\
\hline 19 & ojczyzna & 4 \\
\hline 20 & piękno & 3 \\
\hline
\end{tabular}


Na podstawie analizy rysunków przedstawiających wartości najbardziej cenione przez uczniów można stwierdzić, że wartościami najbardziej preferowanymi przez badanych są: rodzina, wartości religijne (Bóg, Pan Jezus), miłość, dom (można w zasadzie uznać „dom” za symbol rodziny, jednak w badaniach uznano, że jest to odrębna wartość - miejsce ważne dla dziecka, gdzie czuje się ono bezpiecznie, dobrze), nauka, przyjaźń, zdrowie.

$\mathrm{Na}$ podstawie przeprowadzonych obliczeń statystycznych i przy wykorzystaniu testu Chi-kwadrat stwierdzono, że płeć, miejsce zamieszkania, wykształcenie rodziców wpływa w pewnym stopniu na sposób udzielania odpowiedzi na powyższy problem, jednak różnice nie są istotne statystycznie $(\mathrm{p}>0,05)$.

Najważniejszą wartością w życiu chrześcijanina jest Bóg. Wartości święte w Schelerowskiej hierarchii wzorcowej uznane są za wartości najwyższe. Wartością najbardziej cenioną przez uczniów (na podstawie kwestionariusza ankiety) klas III okazał się Bóg. Dla badanych rodziców również wartością najważniejszą są świętości religijne (na podstawie badania SWS). Można więc stwierdzić, że dla dzieci - tak jak i dla ich wychowawców wartości religijne są bardzo ważne.

Do wartości społecznych możemy zaliczyć między innymi: patriotyzm, ojczyznę, rodzinę, miłość, niepodległość, pokój, sprawiedliwość. Wartości te, za autorem SWS, P. Brzozowskim, możemy nazwać świętościami świeckimi. Wartości te zostały wysoko ocenione przez badanych uczniów i ich rodziców. Wartości poznawcze: mądrość, wiedza, prawda, poznanie, są niemal w takim samym stopniu cenne dla wychowawców, jak i ich podopiecznych.

Wartości moralne (dobro, uczciwość, sprawiedliwość), szczególnie w ujęciu aksjologii personalistycznej, odgrywają ważną rolę w życiu człowieka. Wpływają na jakość życia człowieka, jego duchową dojrzałość, pomagaja zrozumieć potrzeby innych ludzi. Rodzice w badaniu SWS umieścili wartości moralne na 3 miejscu, po świętościach religijnych i świętościach świeckich. Dla dzieci wartości te są mniej ważne (porządkując wartości, dobru przyznali ostatnie -7 - miejsce).

\section{Wnioski}

1. Przeprowadzone badania empiryczne ukazuja, iż rodzina odgrywa bardzo ważną rolę w wychowaniu do wartości dzieci w młodszym wieku szkolnym.

2. Wartościami, które badani rodzice uważają za najważniejsze w ich życiu, są: Bóg, rodzina, patriotyzm. 
3. Dzieci wybierały wartości podobne do tych, które cenią ich rodzice (Bóg, rodzina, miłość). Tak więc za wychowanie do wartości dzieci w młodszym wieku szkolnym odpowiedzialni są przede wszystkim rodzice, którzy są największym autorytetem dla swoich dzieci.

\section{Christian Values in Young Learners Education (Summary)}

This article is devoted to the role of family environment in shaping the values of a young learner. A child's personality is set at an early school age. It is a special period of a child's susceptibility to formative influences and his increased cognitive curiosity. A theoretical section of the article explicates the notion of Christian values and looks at the process of values-oriented education as well at as the role of family environment in values-oriented education of young learners. The empirical section of the article presents findings of research into Christian values-oriented education of young learners. The research was carried out involving 310 grade three students and 310 parents. The research has proven that family plays a crucial role in valuesoriented education of young learners. The parents have viewed God, family and patriotism as prime values in their lives. The children have made a choice of the values similar to those which their parents hold in high regards (God, family, patriotism). 